FACTA UNIVERSITATIS

Series: Law and Politics Vol. 15, No 4, 2017, pp. 375 - 383

https://doi.org/10.22190/FULP1704375M

Review Paper

\title{
TEMPORARY MEASURES IN CRIMINAL PROCEEDINGS AGAINST JUVENILES
}

\author{
UDC 343.224-053.6
}

\author{
Marija Milojević \\ University of Niš, Faculty of Law, Niš, Republic of Serbia
}

\begin{abstract}
The specific nature of juvenile delinquency and the all-present tendency of diverse response to juvenile crime have resulted in distinguishing juvenile criminal law as a separate branch of criminal law. Juvenile criminal law entails special temporary measures which, as such, do not exist in the proceedings against adult individuals. In this paper, the author will point out their characteristics and analyse the concepts of temporary accommodation and referral of juveniles to professional institutions for further assessment. The paper also provides an explanation of the extent to which the international standards on juveniles are observed in our legislation in terms of these temporary measures. The adoption and subsequent application of the Act on Juvenile Criminal Offenders and Protection of Minors in Criminal Law (hereinafter: the Juvenile Justice Act) has proven to be a positive turning point in the regulation of temporary measures. Thus, there is no need for significant reforms except for slight changes, which will be pointed out in this paper. The new draft of the Juvenile Justice Act does not bring substantial changes in this area. This paper provides an overview of the amended provisions and analyzes their purpose and implications.
\end{abstract}

Key words: juvenile delinquency, temporary measures, temporary accommodation, limitation of personal freedom, referral to professional institutions.

\section{INTRODUCTION}

The Act on Juvenile Criminal Offenders and Protection of Minors in Criminal Law (hereinafter: the Juveniles Justice Act), which came into force on $1^{\text {st }}$ January 2006, comprehensively regulates the status of juveniles in criminal law by encompassing the substantive and the procedural provisions, as well as the provisions on the execution of criminal sanctions and measures against juvenile offenders. ${ }^{1}$ The rationale for adopting this

Received June $9^{\text {th }}, 2017$ / Accepted December $4^{\text {th }}, 2017$

Corresponding author: Marija Milojević, LL.M., PhD student, Faculty of Law, University of Niš, Trg Kralja Aleksandra 11, Niš, Serbia

E-mail: milojevicm989@gmail.com

${ }^{1}$ Before enacting this Act, the criminal-law status of juveniles was regulated by different laws: the substantive criminal law provisions on juveniles were included in the Criminal Code, the procedural-law provisions were placed in a separate chapter of the Criminal Procedure Code (where the proceedings against juveniles were regulated as a specific 
act is to be found in the international standards in the field of juvenile justice ${ }^{2}$ but, primarily, in specific biological and psycho-social characteristics of juvenile delinquents who require a different reaction of the state to their delinquent behaviour, which implies a more frequent use of diversion measures and avoiding the harmful consequences of regular criminal proceedings.

The Juvenile Justice Act (2006), among other things, recognizes and regulates the temporary measures of supervision and protection of juvenile criminal offenders during criminal proceedings. These measures include the measure of temporary accommodation and the measure of referring a juvenile to a professional institution or shelter if there is a need to assess the juvenile's personal traits. The temporary accommodation of juveniles is a measure which is not envisaged in the Criminal Procedure Code (CPC), which regulates the proceedings against adult criminal offenders, whereas the measure of referring a juvenile to a professional institution or shelter may be applied to adult offenders (under the CPC) but it exhibits certain specificities during the proceedings involving juveniles. Due to the specific nature of these measures, there are different opinions in theory about the way in which these terms should be qualified and classified.

On the one hand, these are repressive measures because they entail limitation or deprivation of liberty of juveniles, for which reason all authorities participating in the deprivation of liberty have to act with extreme caution ${ }^{3}$.The special UN Rules for the Protection of Juveniles Deprived of their Liberty inter alia imply that deprivation of liberty of juveniles must be conducted under the conditions which ensure respect for the juveniles' human rights ${ }^{4}$, whereby the deprivation of liberty is envisaged as a wider concept referring not only to the deprivation of liberty in the course of criminal proceedings but also in the course of social and health protection proceedings.

On the other hand, these measures are also protective, which is a common feature underlying all legal institutes prescribed by the Juvenile Justice Act. Whereas the obvious purpose of imposing the measure of temporary accommodation is to protect and help a juvenile ${ }^{5}$, the measure of referring juveniles to a professional institution or shelter for further assessment provides for indirect protection and assistance, by deciding to impose a criminal sanction and referring the juvenile to an institution where it will be executed. One of the characteristics of these measures is surely the supervision performed by the professionals from the guardianship authority (social welfare centre), professionals from the institution or shelter in which the juvenile is placed, or the members of the family in which the juvenile is temporarily placed if the case refers to the temporary accommodation in another family. These individuals ensure that a juvenile does not abandon the implementation of the measure.

kind of criminal proceeding), and the execution of criminal sanctions against juveniles was regulated in the Act on the Enforcement of Criminal Sanctions. These laws are still in use but they are an auxiliary rather than the primary source of juvenile criminal law in the Republic of Serbia.

${ }^{2}$ Inter alia, this refers to the 1990 United Nations Standard Minimum Rules for Non-Custodial Measures (the Tokyo rules), the 1985 UN Standard Minimum Rules for the Administration of Juvenile Justice (the Beijing rules), the 1990 UN Rules for the Protection of Juveniles Deprived of Liberty (the Havana rules), etc.

${ }^{3}$ The specific activities against juveniles regarding the deprivation of liberty are envisaged in all significant international documents, especially in the Convention on the Rights of the Child and the Standard Minimum Rules for the Administration of Juvenile Justice - the Beijing rules (Article 13).

${ }^{4}$ Rule No. 12 of the UN Rules for the Protection of Juveniles Deprived of their Liberty (the Havana rules), 1990; http://ombudsman.npm.rs/attachments/5\%20Pravila\%20UNa.pdf (retrieved 1 April 2017)

${ }^{5}$ Article 66 of the Act on Juvenile Criminal Offenders and Protection of Juveniles in Criminal Law (hereinafter: the Juvenile Justice Act), Official Gazette of the Republic of Serbia 55/2014. 
Taking into account the aforesaid characteristics, these measures can also be designated as the measures of supervision and protection of juveniles.

There are also opinions on the sui generis nature of these measures. Therefore, taking into consideration their repressive and protective characteristics, certain authors classify them as temporary measures in the proceedings against juveniles (Škulić, Stevanović, 1999:209). It should be noted that these measures should be strictly differentiated from the temporary measures which are regulated by the Criminal Procedure Code, with which they have nothing in common except for the terminological definition. ${ }^{6}$ These measures are also specific given the role they play in the proceedings against juveniles, which may be procedural and non-procedural at the same time. Their procedural role is reflected in providing the presence of juveniles in the criminal proceedings and establishing the case facts, while their non-procedural role is reflected in the re-socialisation of juveniles, their treatment and separation from the environment which has a harmful effect on them.

Taking into account the complexity and all aspects of these legal institutes, the author has analysed these measures separately, in light of their classification as temporary measures in the proceedings against juveniles.

\section{TEMPORARY ACCOMMODATION OF JUVENILES}

Temporary accommodation of juveniles is the measure of depriving juveniles of liberty in the course of criminal proceedings, which is characteristic only for juvenile criminal law; thus, unlike other procedural enforcement measures which are prescribe in the Criminal Procedure Code (such as: summons, apprehension, detention) and which can be applied against adults, this measure can be imposed only on juvenile criminal offenders. This form of deprivation of liberty of juveniles has a distinctive purpose, which should be fulfilled by applying this measure. Namely, the Juvenile Justice Act explicitly prescribes that this kind of limitation of liberty is imposed only when it is necessary to separate the juvenile from the environment in which he/she has lived, or to provide help, supervision or accommodation for juveniles. The aforementioned provision yields a conclusion that the primary goal of this temporary measure is to protect juveniles and to accomplish non-procedural goals (to separate a juvenile from the environment in which he/she lived and to help him/her); in contrast, detention is primarily aimed at achieving procedural goals (to secure the unobstructed course of criminal proceedings) although it may also be used (to a lesser extent) for attaining nonprocedural goals, when it is used to protect the security of people (for example, when detention is imposed to prevent the commission of another criminal offence, completion of a previously attempted offence or threat, or to diminish the aggravation of the general public).

For these reasons, some authors classify temporary accommodation of juveniles as protective measures because, in the course of preparatory proceedings, the juvenile judge has to take into account the harmful effects of the juveniles' immediate living environment and to protect him/her from the harmful impact of that environment (Đurđić, 2011:288).

However, other authors include this measure in the part where they discuss the application of procedural enforcement measures in the proceedings against juveniles (Knežević, 2009:385-397; Knežević, 2010:156-167). The reason for considering the measure of

\footnotetext{
${ }^{6}$ Temporary measures against adult criminal offenders primarily serve to secure the compensation claim arising from the committed criminal offence; thus, they are prescribed in the section of CPC which specifically refers to the compensation claim.
} 
temporary accommodation of juveniles within the scope of procedural enforcement measures lies in the fact that temporary accommodation is a form of limitation on the juveniles' liberty (to a lesser or greater extent, depending on whether the juvenile is accommodated into an appropriate institution, placed under the supervision of the guardianship authority, or sent into another family); this is the essence of applying procedural enforcement measures against adults as well as against juvenile criminal offenders (summons and apprehension as the mildest measures of procedural enforcement also represent a form of limitation of liberty, but to the smallest extent possible; it also refers to detention as the strictest measure which includes deprivation of the defendant's freedom of movement).

Another reason for classifying temporary accommodation into procedural enforcement measures is supported by the fact that the purpose of this measure is not only to protect but also (as it may be inferred from the provisions of the Juvenile Justice Act) to achieve some procedural goals, which can only be attained by imposing detention. ${ }^{7}$ Namely, the context of the provision on detention, which prescribes that detention can be imposed if the purpose of depriving a juvenile of liberty cannot be fulfilled by temporary accommodation, leads to the conclusion that this measure can be used for achieving certain procedural goals which can be attained by detention (for example, preventing an escape attempt or securing the presence of a juvenile in the proceedings). Thus, a juvenile who has been imposed the measure of temporary accommodation in a shelter, correctional facility or a similar institution will be prevented to escape or commit a new criminal offence. The extension of the normative framework of this measure and its regulation as a measure of securing the juveniles presence in criminal proceedings is further supported by the fact that it would significantly contribute to reducing the use of detention in the proceedings against juveniles; in particular, it could be achieved by placing the juvenile into another family or by putting him/her under the supervision of the guardianship authority, and the procedure may also include some non-custodial procedural enforcement measures, as suggested in comparative law literature (Knežević, 2009: 394-395).

The provision in Article 66 of the Juvenile Justice Act prescribes that, in the preparatory proceedings, a juvenile judge can issue a decision on temporary accommodation of a juvenile into a shelter, a correctional facility or a similar institution, to place the juvenile into another family, or to put him/her under supervision of the guardianship authority, in case it is necessary to isolate the juvenile from the harmful living environment or to provide help, supervision, protection or accommodation. Therefore, in order to impose this measure, two conditions have to be met: the formal/procedural and the substantive one. The procedural condition is embodied in two elements: a) the personal and subject-matter jurisdiction of the juvenile judge to decide on the matter at the specific stage in the proceedings (in the preparatory proceedings); and b) the decision shall be issued in the form of a judicial decision. The substantive condition entails the court assessment that the implementation of the accommodation and/or supervision measures is necessary in order to achieve one of the two alternatively formulated goals: 1) if it is necessary in order to isolate the juvenile from the harmful living environment, or 2) in order to provide help, supervision, protection or

\footnotetext{
${ }^{7}$ In the Croatian Law, temporary accommodation of juveniles is focused on the achievement of not only socialpedagogical (protection of juveniles from endangering their own development), but also procedural goals (prevention of repeating the same offence), and such a conclusion can be made from the provision of Article 72 of the Juvenile Courts Act of the Republic of Croatia, because these goals are specifically emphasized for the decision on temporary accommodation of juveniles.
} 
accommodation of juveniles. The second goal is considered fulfilled if the measures are used for attaining any of the four specific goals (Škulić, et al., 1999: 210-211).

The former legal solutions on criminal proceedings against juveniles, previously regulated in the separate chapter of the Criminal Procedure Code, prescribed that the measure of temporary accommodation of a juvenile could be imposed during the entire course of proceedings, either by a juvenile judge or the judicial panel (depending on the stage of proceedings when the measure is ordered: in a preparatory proceeding or during the proceeding before the judicial panel). ${ }^{8}$ The provision did not specify the legal form of the decision on imposing the measure of temporary accommodation of juveniles; however, considering the use of the verb 'order' in the formulation of the legal provision, it was interpreted in legal theory that the decision should be made in the form of a court order, although there were authors who considered that the decision should be made in the form of $a$ judicial decision. This dilemma was resolved in the Juvenile Justice Act (2006), which precisely defines that the decision on temporary accommodation of juveniles shall be rendered in the form of a judicial decision. It seems to be a more suitable solutions because it provides for the right to an appeal to authorized individuals, especially taking into consideration that it implies a significant limitation of juveniles' freedom and interference with human rights; thus, there is a need for positive law solution which would institute judicial control over the decision on temporary accommodation.

An appeal against the decision of the juvenile judge regarding the temporary accommodation of juveniles may be filed (within 24 hours) by the juvenile, his/her parents, an adoptive parent, a guardian, a defence counsel, and a public prosecutor for juvenile offenders. The appeal does not postpone the enforcement of the decision, in accordance with the principle of urgency of the actions of competent authorities in the proceedings against juveniles. The Act explicitly prescribes that the accommodation expenses are paid in advance from the court budget ${ }^{9}$ and are treated as costs of criminal proceedings, which means that the final decision on them will depend on the way the proceedings end, and the type of final decision rendered by the judicial panel for juveniles. What is not precisely determined in the Act is who decides on the appeal to the judicial decision on temporary accommodation of juveniles; given the fact that the time limit for filing an appeal is extremely short (24 hours), the urgency of the proceeding requires that the judicial council for juveniles offenders at the court of first instance decides on the appeal (Perić, 2005:166).

The cases where this temporary measure is most frequently applied are as follows: a) when, under the influence of the immediate living environment, the juvenile demonstrates some disorders in his/her behaviour, such as: beggary, vagrancy, gambling, truancy; b) when parents solicit their children for sexual services, or compel them to beg or gamble; c) when children are abandoned and/or left without any means of subsistence; d) when children abandon their family and are left with no accommodation (Ilić, 2003: 115).

It may be noted that the main shortcoming of the legal solutions on imposing the measure of temporary accommodation of juveniles is that the Juvenile Justice Act does not envisage the length of this measure; such a provision is essential considering the urgency of the

\footnotetext{
${ }^{8}$ Article 473, the Criminal Procedure Code of the Republic of Serbia, Official Gazette of the Republic of Serbia, 72/2011, 101/2011, 121/2012, 32/2013, 45/2013, 55/2014.

${ }^{9}$ The necessity of this measure and the prescribed purpose which includes the protection of juveniles and the isolation from the environment which threatens him/her, has conditioned the way in which the costs of the temporary accommodation of juveniles are planned in advance, because the planning of costs of this measure, due to great importance, could not be left to the free-will of political parties.
} 
proceedings against juveniles as well as the fact that this measure implies the limitation of juveniles' freedom, which should be minimized in compliance with the international standards in this area. This flaw is removed in the new draft of the Juvenile Justice Act, which provides that these measures may be in effect until the end of the juvenile proceedings, except for the measure of temporary accommodation in a shelter, a correctional facility or a similar institution, which may not exceed a period of two months. ${ }^{10}$ The appellants have remained the same, but the time limit for filing an appeal is extended to three days from the day of the receipt of the decision (which is a customary time limit for an appeal to a court decision in criminal procedure law). The draft Act also specifically prescribes that the decision on appeal falls into the functional jurisdiction of the judicial panel (council), comprised of three judges from the court of first instance, which is presided by a judge who possesses specific knowledge from the field of children's rights and juvenile criminal law. Such a legal solution represents a positive step in regulating the measure of temporary accommodation of juveniles; the measure is regulated within the segment including the measures of securing the presence of a juvenile in proceedings, which confirms the author's opinion that the application of this measure contributes to achieving not only protective but also procedural goals. For these reasons, the duration of temporary accommodation of juveniles and any deprivation of liberty should be included in the total length of criminal sanctions against juveniles (Lazarević, Grubač, 2005:129).

Another problem which may appear in practice, during the application of this legal institute, is the process of selecting the family which will accommodate a juvenile if the measure of temporary accommodation is imposed. One of the possible solutions is that this should be the family of the juvenile's closest or most suitable blood relatives, which is to ensure the juvenile's easier adaptation.

\section{THE MEASURE OF REFERRING A JUVENILE TO A PROFESSIONAL InSTITUTION OR SHELTER}

Besides the measure of temporary accommodation of juveniles, some authors draw attention to the measure of referring a juvenile to a professional institution or a shelter if there is a need to examine the personal traits of juveniles. This measure is envisaged in the Juvenile Justice Act, which prescribes as follows: when a juvenile needs to be examined by experts, in order to determine the juvenile's health condition, level of maturity and other personality traits, doctors, psychologists and pedagogues will be appointed for this examination, whereby these examinations can be conducted in a health institution or some other institution.

The ratio legis of this provision shows that it is completely different from the measures of securing the presence of a juvenile during the criminal proceedings, and that it primarily serves to shed light on the facts related to the juvenile's personal traits and to form factual grounds for the subsequent decision of the judicial panel (council for juvenile offenders) on the relevant criminal sanction against the juvenile. For these reasons, this measure is different from the temporary accommodation of juveniles whose purpose is, among other things, to secure the presence of juveniles during the criminal proceedings.

\footnotetext{
${ }^{10}$ Article 61, Paragraph 3, Draft of the Law on Juvenile Criminal Offenders and Criminal Protection of Juveniles, Retrieved 1 May, 2017, from http://www.paragraf.rs/dnevne-vesti/141215/141215-vest40.html.
} 
The similarities between these two measures refer to the repression which is applied against a juvenile, because the referral to a professional institution or a shelter implies the limitation of juveniles' liberty during the time needed to examine his/her personal traits. They are included into the category of temporary measures due to the fact that they both serve to provide protection and assistance to a juvenile, whereby the temporary accommodation refers to direct protection, while the referral to a professional institution or a shelter implies indirect protection. Although the current legislation does not prescribe the duration of these measures, they are temporary and of limited duration; thus, they will be cancelled when there is no need for them to be enforced, and their duration shall be reduced to the shortest period possible.

One of the flaws of this legal provision is the fact that the referral of juveniles to medical or other institutions is not time-limited, which may lead to possible abuses in practice and detaining a juvenile longer than it is necessary. This is inconsistent with the international standards in the field of juvenile criminal justice, under which any limitation of juveniles' liberty needs to be reduced to the shortest period possible. ${ }^{11}$ If we compare this measure with the measure of placing a defendant into a health institution for the purpose of expert examination which exists in the Criminal Procedure Code (CPC), we may notice that the same measure is more fully regulated in the proceedings against adults because of the stated duration of this measure ( 15 days at the most, but in exceptional cases it can be extended for another 15 days); moreover, the CPC provision includes the possibility of filing an appeal against this decision, which is not the case in the proceedings against juveniles.

This drawback has not been removed in the new draft of the Juvenile Justice Act, in spite of the fact that the issue of deprivation of liberty should be given more attention considering their age, immaturity and psycho-physical characteristics prominent in different developmental periods. Juveniles are more prone to the harmful effect of their immediate environment and accommodation into an institution than adults. For this reason, the intention of the legislator to provide a more detailed and comprehensive regulation on the deprivation of defendant's liberty in regular proceedings remains unclear.

\section{CONCLUSION}

In criminal proceedings against juveniles, temporary measures are necessary for ensuring an efficient course and termination of criminal proceedings. Although these measures entail the limitation on juveniles' personal freedom, they are crucial for the accomplishment of many procedural and non-procedural goals. For these reasons, they are envisaged in all European legislations. Juvenile criminal law is based on the increased protection of juveniles in criminal proceedings, in which case there is the so-called "positive discrimination of citizens" (Škulić, 2013:45). This is the ratio legis of their inclusion in the Serbian positive law.

Temporary accommodation of juveniles is the measure which can be used for accomplishing detention goals; it implies the attainment of both procedural and nonprocedural (protection) goals, which makes its existence entirely justified and logical, considering the character of criminal proceedings against juveniles. In many international instruments (such as: the Convention on the Rights of the Child, the Beijing rules, the Havana

\footnotetext{
${ }^{11}$ The Convention on the Rights of the Child states that no child shall be deprived of his/her liberty unlawfully or arbitrarily, as well as that the arrest, detention or imprisonment of a child shall be in conformity with the law and shall be used only as a measure of last resort and for the shortest appropriate period of time. Article 37 , paragraph 2 of the Convention on the Rights of the Child.
} 
rules, etc.), there is a tendency that arrest, detention and imprisonment of the child ${ }^{12}$ shall be applied only as the last possible measure, for the shortest period possible; instead, alternative measures (such as: supervision or placing a juvenile into another family or an educational institution) shall be used as much as possible. Therefore, the need to limit the liberty of juvenile offenders in order to achieve procedural goals in criminal proceedings has not stopped, but its application is more restrictive than in regular criminal proceedings.

In Serbian positive legislation, the measure of temporary accommodation of juveniles is in accordance with the international standards. Based on the draft of the new Juvenile Justice Act, it seems that the future legislative act will keep the course of the previous one, whereby the amended provisions will remove the minor deficiencies indicated in this paper. The new draft sets the maximum duration of temporary accommodation and underscores that detention should be used as the last resort; as for juvenile offenders, detention can be imposed on a younger juvenile only in case he/she has committed a criminal offence which is punishable by a term of three years' imprisonment or a more severe punishment.

Finally, it should be noted that the measure of referring a juvenile juvenile to a professional institution or a shelter, in case there is a need to examine the personal traits of the juvenile offender, has been inadequately prescribed in the Juvenile Justice Act. Considering the distinctive features of criminal proceedings against juvenile offenders, it is unacceptable that there is no possibility of filing an appeal against the judicial decision on this matter, and that there is no time limit on the duration of this measure.

\section{REFERENCES}

Đurđić, V., (2011). Krivično procesno pravo-posebni deo [Criminal Procedure Law: Special part], Sven, Niš.

Ilić, R., (2003). Položaj maloletnika u krivičnom postupku-magistarska teza [Position of Juveniles in Criminal Proceedings - Master thesis], Niš.

Knežević, S., (2009). Primena procesne prinude prema maloletnicima [The Application of Procedural Enforcement against Juveniles], / In: Petrušić, N., (ed.), Projekat „Pravo na pristup pravosuđu“, Instrumenti za implementaciju evropskih standarda u pravni sistem RS/, Niš, 2009, Knj.3, pp. 385-397.

Knežević, S., (2010). Maloletničko krivično pravo-materijalno, procesno i izvršno [Juvenile Criminal Law: substantive, procedural and execution aspects], Punta, Niš.

Convention on the Rights of the Child, (1989), Retrieved 1 April 2017 from http://www.unicef.org/serbia/ Konvencija_o_pravima_deteta_sa_fakultativnim_protokolima(1).pdf).

Lazarević Lj., Grubač, M., (2005), Komentar Zakona o maloletnim učiniocima krivični dela i krivičnipravnoj zaštiti maloletnih lica [Comment on the Act on Juvenile Criminal Offenders and Criminal-law Protection of Juveniles], Beograd.

Draft of the Act on Juvenile Criminal Offenders and Criminal-law Protection of Juveniles, Retrieved 1 May 2017 from http://www.paragraf.rs/dnevne-vesti/141215/141215-vest40.html.

Perić, O., (2005). Komentar Zakona o maloletnim učiniocima krivični dela i krivičnipravnoj zaštiti maloletnih lica [Comment on the Act on Juvenile Criminal Offenders and Criminal-law Protection of Juveniles], Službeni glasnik, Beograd.

The United Nations Rules for the Protection of Juveniles Deprived of their Liberty (the Havana rules), 1990, Retrieved 1 April 2017 from http://ombudsman.npm.rs/attachments/5\%20Pravila\%20UNa.pdf.

The United Nations Standard Minimum Rules for Non-custodial Measures (the Tokyo rules), 1990, Retrieved 1 April 2017 from http://ombudsman.npm.rs/attachments/6\%20Tokijska\%20pravila.pdf.

The Standard Minimum Rules for the Administration of Juvenile Justice (the Beijing rules), 1985, Retrieved 1 April 2017 from http://www.unicef.org/serbia/3PekinskaPravila(1).pdf.

\footnotetext{
${ }^{12}$ This term is used in the Convention on the Rights of the Child for referring to individuals younger than 18 .
} 
Škulić, M., (2013). Osnovni evropski standardi u krivičnom postupku Srbije [Basic European standards in the criminal proceeding of Serbia], /nn: Kron, L., Jugović, A., (eds.), Kriminal, državna reakcija i harmonizacija sa evropskim standardima [Crime, state response and harmonization with the European standards]/.- Beograd, Institut za kriminološka i sociološka istraživanja, 2013, pp.29-57.

Škulić, M., Stevanović, I., (1999). Maloletni delinkventi u Srbiji, Neka pitanja materijalnog procesnog $i$ izvršnog prava [Juvenile delinquents in Serbia, Certain issues of substantive, procedural and execution law], Jugoslovenski centar za prava deteta, Beograd.

Zakon o maloletnim učiniocima krivični dela i krivičnipravnoj zaštiti maloletnih lica [The Act Juvenile Criminal Offenders and Criminal-law Protection of Juveniles], Službeni glasnik Republike Srbije, br. 85 (2005).

Zakonik o krivičnom postupku [The Criminal Procedure Code of the Republic of Serbia], Službeni glasnik Republike Srbije, br. 72 (2011), 101 (2011), 121 (2012), 32 (2013), 45 (2013), 55 (2014).

\section{PRIVREMENE MERE U KRIVIČNOM POSTUPKU PREMA MALOLETNICIMA}

Specifična priroda maloletničke delinkvencije kao i sveprisutna tendencija diverzionog reagovanja na maloletničko prestupništvo, rezultirala je izdvajanjem maloletničkog krivičnog prava kao posebne grane krivičnog prava koja obuhvata odredbe materijalnog, procesnog i izvršnog krivičnog prava. Maloletničko krivično pravo odlikuje i postojanje posebnih privremenih mera koje kao takve ne postoje u postupku prema punoletnim licima. U daljem radu autor će ukazati na njihove karakteristike i izvršiće analizu pojmova privremenog smeštaja maloletnika i upućivanja maloletnika u stručnu ustanovu ili prihvatilište ukoliko je potrebno ispitati lična svojstva maloletnika. Takođe, objašnjava se u kojoj meri su međunarodni standardi o maloletnicima ispoštovani u našem pozitivnopravnom zakonodavstvu $u$ pogledu privremenih mera, ističu se sličnosti i razlike između postupaka prema maloletnom i prema punoletnom licu. Pokazaće se da je Zakonom o maloletnim učiniocima krivičnih dela i krivičnopravnoj zaštiti maloletnih lica učinjen pozitivan zaokret u dosadašnjem regulisanju privremenih mera i da ne postoji potreba za značajnijim reformama osim neznatnih izmena na koje će ovim radom biti ukazano. Novim nacrtom Zakona o maloletnicima ne dolazi do značajnijih promena u ovoj oblasti, ipak autor $u$ ovom radu daje i pregled izmena u novom nacrtu uz analizu njihove neophodnosti i svrsishodnosti.

Ključne reči: privremene mere, privremeni smeštaj maloletnika, ograničenje lične slobode maloletnika, mera upućivanja maloletnika u stručnu ustanovu ili prihvatilište. 